\title{
Trial of Disodium Cromoglycate in Bronchial Asthma
}

\author{
D. G. ROBERTSON,* M.B., M.R.A.C.P.; S. W. EPSTEIN,* M.D., F.R.C.P.C. ; D. A. WARRELL, † B.M., M.R.C.P.
}

\begin{abstract}
Summary : In a double-blind cross-over trial of $S$ disodium cromoglycate on 11 patients nine were symptomatically improved, and in all of these daily measurements of peak expiratory flow increased. The forced expiratory volume in the first second and specific airway conductance did not increase in all patients. In most cases the average values for residual volume and functional residual capacity fell; exercise capacity and ventilation did not change, but the pulse rate on exercise was lower. It is suggested that the changes produced by disodium cromoglycate are worth while.
\end{abstract}

\section{Introduction}

Disodium cromoglycate was recently introduced as a treatment for bronchial asthma. Howell and Altounyan (1967) reported that it produced symptomatic improvement; in particular it reduced the frequency and severity of acute attacks, cough, and sputum volume. In some cases they were able to reduce the dose of corticosteroid (Altounyan and Howell, 1967). But not all patients who improved symptomatically showed an increase in forced expired volume in the first second (F.E.V..$_{1}$ ). The authors suggested that many symptoms associated with asthma, such as intermittent attacks of breathlessness at rest, cough, sputum, and morning tightness of chest, may not be reflected in isolated measurements of F.E.V..$_{1}$.

In order to study this question further we have made more detailed observations in a group of asthmatics who, on the basis of Altounyan and Howell's experience, seemed likely to respond to disodium cromoglycate. These patients took part in a double-blind cross-over trial in which symptoms were recorded and various measurements were made. The results were analysed in an attempt to discover an objective basis for their subjective improvement.

\section{Materials and Methods}

Eleven volunteers with bronchial asthma were accepted for the trial (Table I). Prick skin tests were positive to two or more Bencard allergens in all the patients. Five had histories of cough and sputum consistent with a diagnosis of simple chronic bronchitis (M.R.C., 1965). Three were cigarette smokers at the time of the trial. Seven were receiving corticosteroids.

* Research Fellow.

t Medical Registrar.

Department of Medicine, Royal Postgraduate Medical School, London W.12.
Before the trial was started the patients were stabilized for at least one week on a fixed dose of their usual drugs. During the trial they were asked not to alter their dose of tablets, and to record the frequency with which they used aerosol bronchodilator.

The active and placebo preparations were given each for two weeks, the order being randomized. Each preparation was made up into capsules and inhaled four times daily from a special device to dispense the powder in a fine suspension (Spinhaler). The placebo capsules contained isoprenaline sulphate $0.1 \mathrm{mg}$., sodium sulphate $5 \mathrm{mg}$., and lactose. The active preparation consisted of disodium cromoglycate $20 \mathrm{mg}$., isoprenaline sulphate $0.1 \mathrm{mg}$, and an inert carrier.

The patients were given forms on which to record the severity of symptoms each day and each night. The symptoms recorded were breathlessness, tightness of chest, wheeze, cough, and sputum volume. For the first four the patients allocated a number on a scale from 0 to 10 . Zero was taken to mean that the symptom was not present and 10 meant extreme or intolerable severity. As a guide the patients were told that 1-3 was mild, 4-6 moderate, and 7-9 severe. Reduction of activity or sleep was to be recorded as 4 or more. A different scale was used for sputum volume, 0 was none, 1 a few blobs, 2 half to two eggcups, and 3 a larger volume. The patient recorded three values for peak expiratory flow (P.E.F.) with a Wright meter each morning before taking any drugs and three values each evening at least three hours after taking any drugs. The 21 values obtained each morning and evening during the second week of each course were averaged.

After each course of capsules the patient attended the laboratory for spirometry, body plethysmography, an exercise test, and an atropine test. The F.E.V., and vital capacity (V.C.; were recorded with a dry spirometer (McDermott et al. 1968). Three readings of each were taken and averaged. A constant volume body plethysmograph was used to obtain values for airway resistance and lung volume (Guyatt et al., 1967a). Specific conductance was calculated by dividing the reciprocal of airway resistance by the lung volume at which the observation was made (Guyatt et al., 1967b).

The patient then exercised on an electrically braked bicycle ergometer (Elema). The fractional concentration of carbon dioxide in the tidal breaths was measured by an infrared analyser (URAS, Godart, C.P.I.) calibrated with standard gases which had been analysed in the Lloyd-Haldane apparatus. A value for the resting mixed venous carbon dioxide tension was

TABLE I.-Clinical Details of Patients

\begin{tabular}{|c|c|c|c|c|c|c|c|c|c|c|c|}
\hline $\begin{array}{l}\text { Case } \\
\text { No. }\end{array}$ & Age & Sex & $\begin{array}{c}\text { Height } \\
(\mathrm{cm} .)\end{array}$ & $\begin{array}{c}\text { Weight } \\
\text { (kg.) }\end{array}$ & $\begin{array}{l}\text { Duration } \\
\text { of } \\
\text { Asthma } \\
\text { (Years) }\end{array}$ & $\begin{array}{l}\text { Family } \\
\text { History of } \\
\text { Allergic } \\
\text { Disease }\end{array}$ & $\mid \begin{array}{c}\text { Highest } \\
\text { Recorded Blood } \\
\text { Eosinophil } \\
\text { Count }\end{array}$ & $\begin{array}{c}\text { Highest Grade* } \\
\text { of Sputum } \\
\text { Eosinophilia } \\
\text { During Trial }\end{array}$ & $\begin{array}{c}\text { Dose of } \\
\text { Corticosteroid } \\
\text { Throughout } \\
\text { Trial (mg./day) }\end{array}$ & $\begin{array}{l}\text { F.E.V.1 } \\
\text { Before } \\
\text { Trial } \\
\text { (ml.) }\end{array}$ & $\underset{(\mathrm{ml} .)}{\text { Vital }}$ \\
\hline $\begin{array}{r}1 \\
2 \\
3 \\
4 \\
5 \\
6 \\
7 \\
8 \\
9 \\
10 \\
11\end{array}$ & $\begin{array}{l}34 \\
24 \\
29 \\
62 \\
58 \\
13 \\
20 \\
30 \\
55 \\
26 \\
26\end{array}$ & $\begin{array}{c}F \\
M \\
M \\
M \\
F \\
M \\
F \\
M \\
M \\
F \\
F\end{array}$ & $\begin{array}{l}172 \\
176 \\
177 \\
162 \\
160 \\
160 \\
156 \\
174 \\
167 \\
159 \\
168\end{array}$ & $\begin{array}{l}70 \\
62 \\
69 \\
55 \\
50 \\
40 \\
85 \\
70 \\
64 \\
65 \\
61\end{array}$ & $\begin{array}{r}26 \\
22 \\
28 \\
1 \\
21 \\
9 \\
13 \\
3 \\
6 \\
12 \\
16\end{array}$ & $\begin{array}{l}+ \\
+ \\
+ \\
+\end{array}$ & $\begin{array}{r}800 \\
840 \\
450 \\
70 \\
400 \\
1,750 \\
0 \\
270 \\
1,120 \\
490 \\
220\end{array}$ & $\begin{array}{c}2-3 \\
2-3 \\
1 \\
2 \\
2-3 \\
3 \\
0 \\
2-3 \\
3 \\
3 \\
0\end{array}$ & $\begin{array}{c}5 \\
5 \\
10 \\
\\
20 \\
10+ \\
10 \\
2 \cdot 5\end{array}$ & $\begin{array}{r}2,100 \\
1,400 \\
1,370 \\
770 \\
1,150 \\
480 \\
2,000 \\
1,950 \\
1,900 \\
1,670 \\
2,070\end{array}$ & $\begin{array}{l}3,680 \\
2,940 \\
2,400 \\
1,560 \\
2,250 \\
1,580 \\
3,000 \\
5,500 \\
3,650 \\
3,100 \\
2,670\end{array}$ \\
\hline
\end{tabular}

* Graded from 0 to 3 . This patient increased his dose to $25 \mathrm{mg}$. while taking placebo. 
obtained by the rebreathing method, the equilibrium criteria of Campbell and Howell (1962) being used. This value was corrected as suggested by Jones et al. (1967). The electrocardiogram was continuously recorded.

The patient started exercising at a work-load of $100 \mathrm{kp} . \mathrm{m} . /$ minute for one minute. The load was then increased by 100 kp.m./minute each minute until the patient was unable to continue.

Inspired volumes were measured with a dry gas meter (Parkinson Cowan, type CD4) at the end of each minute, and converted to litres corrected for body temperature, pressure, and saturation. The heart rate was calculated at the end of each work-load. Figures for minute ventilation, tidal volume, and pulse rate were taken for each patient at the maximum load which was common to both days of testing. This was done to eliminate differences arising from the completion of a higher final work-load on one of the test days.

After resting for at least 15 minutes the F.E.V.. was again recorded. The patient then inhaled for one minute a solution of $0.2 \%$ aqueous atropine methylnitrate from a Wright nebulizer driven by air at a flow rate of $8 \mathrm{l} . / \mathrm{min}$. One hour later the F.E.V..$_{1}$ was again recorded, an inhalation of $1 \%$ aqueous isoprenaline sulphate was given in the same way, and a further set of F.E.V..$_{1}$ values were obtained five minutes later.

The atropine response was then calculated: atropine response $\%=\frac{\text { change in F.E.V. } \cdot_{1} \text { after atropine }}{\text { change in F.E.V. } \cdot_{1} \text { after atropine and isoprenaline }} \times$

\section{Results}

All 11 patients completed the trial. The placebo was given first in five and the active preparation first in six.

Nine patients had lower scores for breathlessness, tightness of chest, and wheeze combined while taking the active preparation (Table II). Of these nine seven had less cough and six less sputum. Six used their inhaler less frequently. All the patients who improved symptomatically had an increase in their average morning and evening P.E.F. measurements. The difference in the mean values for both morning and evening results in these patients was highly significant $(P<0.01)$.

The results of the other physiological tests performed on the nine patients who improved symptomatically varied (Tables III and IV). F.E.V. increased in six of the nine and the average for all nine increased by $460 \mathrm{ml}$. (33\%). The average increase

TABLE III.-Results of Spirometry and Body Plethysmography in Nine Patients

\begin{tabular}{|c|c|c|c|c|}
\hline Test & $\begin{array}{c}\text { Mean After } \\
\text { Placebo }\end{array}$ & $\begin{array}{c}\text { Mean After } \\
\text { Drug }\end{array}$ & $\begin{array}{c}\text { Mean } \\
\text { Change } \\
\text { After } \\
\text { Drug }\end{array}$ & $\begin{array}{c}\text { Value of } \\
\text { P for } \\
\text { Mean } \\
\text { Difference }\end{array}$ \\
\hline $\begin{array}{l}\text { F.E.V.1 (ml.) } \\
\text { F.E.V.i } / \text { V.C. }(\%) \\
\text { Specific }\end{array}$ & $\begin{array}{c}1,380(580) \\
44(16)\end{array}$ & $\begin{array}{c}1,840(680) \\
55(18)\end{array}$ & $\begin{array}{l}+460(530) \\
+11(9)\end{array}$ & $\begin{array}{l}0.031 \\
0.010\end{array}$ \\
\hline $\begin{array}{ll}\text { conductance } & \\
\text { F.R.C.(1.) } & \ldots \\
\text { R.V.(1.) } & \text {. } \\
\text { T.L.C. (1.) } & \text {. }\end{array}$ & $\begin{array}{c}0.078(0.042) \\
4.3(0.9) \\
3 \cdot 0(0.8) \\
6 \cdot 1(1.3)\end{array}$ & $\begin{array}{c}0.127(0.059) \\
3.7(0.7) \\
2.4(0.6) \\
5.9(0.5)\end{array}$ & $\begin{array}{c}+0.049(0.061) \\
-0.6(0.7) \\
-0.6(0.8) \\
-0.2(0.5)\end{array}$ & $\begin{array}{l}0.047 \\
0.045 \\
0.060 \\
0.32\end{array}$ \\
\hline
\end{tabular}

Figures in parentheses are standard deviations. in V.C. was less, so that the mean value for F.E.V. ${ }_{1} /$ V.C. $\%$ increased significantly. Specific conductance increased in the same six subjects who had an increase in F.E.V.. . Functional residual capacity (F.R.C.) fell in seven and the residual volume (R.V.) fell in eight. The average values for F.R.C. and R.V. for all nine patients fell, but there was little change in the average total lung capacity (T.L.C.). There was no significant change in resting $\mathrm{P} \overline{\mathrm{v}} \mathrm{CO}_{2}$, duration of exercise, or ventilation, but the pulse rate on exercise was lower (Table IV).

TABLE IV.-Mean Results of Resting $P \overline{\mathrm{v}} \mathrm{CO}_{2}$ and Exercise Tests in Nine

\begin{tabular}{|c|c|c|c|c|}
\hline \multicolumn{5}{|c|}{ Patients } \\
\hline Test & $\begin{array}{c}\text { Mean After } \\
\text { Placebo }\end{array}$ & $\begin{array}{c}\text { Mean After } \\
\text { Drug }\end{array}$ & $\begin{array}{c}\text { Mean } \\
\text { Change } \\
\text { After } \\
\text { Drug }\end{array}$ & $\begin{array}{c}\text { Value of } \\
\text { P for } \\
\text { Mean } \\
\text { Difference }\end{array}$ \\
\hline $\begin{array}{c}\text { Resting } \mathrm{PVCO}_{2}^{-} \\
(\mathrm{mm} . \mathrm{Hg})\end{array}$ & $43 \cdot 2(8 \cdot 9)$ & $45 \cdot 4(3 \cdot 9)$ & $+2 \cdot 2(7 \cdot 1)$ & 0.38 \\
\hline $\begin{array}{l}\text { Exercise duration } \\
\text { (seconds) } \\
\text { Minute ventilation }\end{array}$ & $400(130)$ & $380(100)$ & $-20(45)$ & 0.30 \\
\hline $\begin{array}{l}\text { at maximum } \\
\text { common load } \\
\text { Tidal volume at }\end{array}$ & $48 \cdot 3(12 \cdot 4)$ & $46 \cdot 3(13 \cdot 3)$ & $-2 \cdot 0(4 \cdot 6)$ & 0.24 \\
\hline $\begin{array}{l}\text { maximum com- } \\
\text { mon load } \\
\text { Pulse rate at maxi- }\end{array}$ & $1,930(860)$ & $1,910(720)$ & $-20(370)$ & 0.87 \\
\hline load .. & $152(25)$ & $146(20)$ & $-6 \quad(7 \cdot 2)$ & 0.03 \\
\hline
\end{tabular}

Figures in parentheses are standard deviations.

For the whole group there was a small increase in atropine response. In the six patients having steroids the increase was very small compared with the large change in the three not having steroids (Table V).

\begin{tabular}{|c|c|c|c|}
\hline & & Mean After Placebo & Mean After Drug \\
\hline $\begin{array}{l}\text { All } 9 \text { patients } \\
6 \text { patients having steroids } \cdots \\
3 \text { patients not having steroids }\end{array}$ & $\ddot{x}$ & $\begin{array}{l}68 \%(18-100) \\
79 \%(55-100) \\
48 \%(18-85)\end{array}$ & $\begin{array}{l}85 \%(66-118) \\
83 \%(66-112) \\
90 \%(75-118)\end{array}$ \\
\hline
\end{tabular}

Ranges in parentheses.

\section{Discussion}

Treatment periods of two weeks were chosen because disodium cromoglycate takes several days to achieve full effect. During a study such as this considerable variation in symptoms will occur in any group of asthmatics. We hoped to overcome this problem by using a randomized double-blind approach.

Symptomatic improvement after disodium cromoglycate was recorded by 9 out of the 11 patients. One patient (Case 2) developed an acute bronchitis while on the drug, and started antibiotic treatment when he changed to placebo; this probably contributed to his subsequent improvement. Apart from the variable use of aerosol bronchodilator by most patients, and of antibiotic in Case 2, the only other change in treatment was in Case 9. This patient increased his steroid dose, took more bronchodilator, and started antibiotic while on placebo during the second period of his trial.

In the nine who recorded a diminution in the combined scores for breathlessness, tightness of chest, and wheeze there was a good correlation between the reduction in score and increase

TABLE II.-Total Symptom Scores for Seven Days, P.E.F. Results

\begin{tabular}{|c|c|c|c|c|c|c|c|c|c|c|c|}
\hline \multirow{2}{*}{$\begin{array}{l}\text { Case } \\
\text { No. }\end{array}$} & \multicolumn{2}{|c|}{$\begin{array}{c}\text { Breathlessness + } \\
\text { Tightness + Wheeze }\end{array}$} & \multicolumn{2}{|c|}{ Cough } & \multicolumn{2}{|c|}{$\begin{array}{l}\text { Sputum } \\
\text { Volume }\end{array}$} & \multicolumn{2}{|c|}{$\begin{array}{c}\text { Spray } \\
\text { Inhalations }\end{array}$} & \multicolumn{3}{|c|}{$\begin{array}{l}\text { P.E.F. } \\
\text { a.m./p.m. }\end{array}$} \\
\hline & Placebo & Drug & Placebo & Drug & Placebo & Drug & Placebo & Drug & Placebo & Drug & $\%$ Change \\
\hline $\begin{array}{r}1 \\
2 \\
3 \\
4 \\
5 \\
6 \\
7 \\
8 \\
9 \\
10 \\
11\end{array}$ & $\begin{array}{r}11 \\
3 \\
15 \\
43 \\
5 \\
143 \\
63 \\
46 \\
177 \\
191 \\
25\end{array}$ & $\begin{array}{r}4 \\
217 \\
11 \\
0 \\
2 \\
107 \\
63 \\
15 \\
40 \\
66 \\
16\end{array}$ & $\begin{array}{r}0 \\
2 \\
10 \\
20 \\
3 \\
32 \\
21 \\
61 \\
62 \\
114 \\
17\end{array}$ & $\begin{array}{r}0 \\
24 \\
8 \\
12 \\
0 \\
28 \\
21 \\
1 \\
21 \\
63 \\
25\end{array}$ & $\begin{array}{r}0 \\
0 \\
2 \\
17 \\
11 \\
19 \\
1 \\
13 \\
40 \\
18 \\
14\end{array}$ & $\begin{array}{r}0 \\
18 \\
7 \\
14 \\
9 \\
10 \\
12 \\
4 \\
21 \\
11 \\
21\end{array}$ & $\begin{array}{r}0 \\
0 \\
79 \\
16 \\
0 \\
77 \\
23 \\
35 \\
123 \\
56 \\
30\end{array}$ & $\begin{array}{r}0 \\
116 \\
85 \\
0 \\
0 \\
36 \\
18 \\
9 \\
45 \\
17 \\
33\end{array}$ & $\begin{array}{c}260 / 275 \\
230 / 255 \\
165 / 190 \\
65 / 70 \\
80 / 95 \\
205 / 220 \\
240 / 265 \\
160 / 180 \\
210 / 275 \\
128 / 151 \\
150 / 210\end{array}$ & $\begin{array}{l}300 / 285 \\
160 / 160 \\
185 / 205 \\
130 / 130 \\
115 / 130 \\
255 / 285 \\
230 / 245 \\
205 / 315 \\
250 / 325 \\
135 / 225 \\
170 / 215\end{array}$ & $\begin{array}{c}+15 /+4 \\
-30 /-37 \\
+12 /+8 \\
+100 /+86 \\
+44 /+37 \\
+24 /+30 \\
-4 /-8 \\
+28 /+75 \\
+19 /+18 \\
+5 /+49 \\
+31 /+2\end{array}$ \\
\hline
\end{tabular}


in average P.E.F. rates in the morning or in the evening. All patients who were symptomatically better had an increase in P.E.F., including the three patients who had a smaller F.E.V..$_{1}$; the use of a peak flow meter is of considerable value in following the response to treatment in asthmatics over a period of days or weeks, and in this trial it provided useful confirmation of symptomatic benefit (Epstein et al., 1969). The degree of symptomatic improvement did not correlate with initial F.E.V. 1 results.

Moran et al. (1968) reported a greater improvement in the younger patients, but in our series the reverse obtained.

In the nine patients there was a reduction in average values of F.R.C. and R.V. Woolcock and Read (1966) found a greater reduction in T.L.C. in many of their cases, whereas only one of our patients showed a fall of as much as 1 litre. The difference may be due to the fact that Woolcock and Read's patients were studied during and after severe status asthmaticus.

We did not find any improvement in exercise capacity in those who were symptomatically better despite an increase in ventilatory capacity as judged by F.E.V..$_{1}$ and specific conductance of airways. It would seem that ventilation did not limit exercise capacity in our subjects, though it would be expected to do so with a greater degree of airway obstruction. The reduction in pulse rate is unexplained.

Altounyan (1964) showed that during attacks of asthma associated with allergy there is a poor response to inhaled atropine methylnitrate compared with isoprenaline sulphate, but that treatment with corticosteroids increases the atropine response. Patients with non-allergic airway obstruction usually have a high atropine response. In the present study the six asthmatics having steroids had a much greater atropine response than those not having steroids. Furthermore, those not having steroids had an increase in atropine response after treatment with disodium cromoglycate. If a poor atropine response indicates an allergic basis for increased airway resistance, both steroids and disodium cromoglycate appear to interrupt this allergic process, not necessarily by the same mechanism. Pepys et al. (1968) showed that previous inhalation of disodium cromoglycate inhibited allergic reactions produced by inhalation of appropriate allergens in asthmatic patients.

We included sensitive tests of airway resistance and lung volumis, using the body plethysmograph, and of exercise performance in our study because we thought that these methods might show a physiological basis for subjective improvement in the absence of improvement in F.E.V..$_{1}$. In fact these more elaborate techniques proved less useful than the simple daily measurement of P.E.F. It seems that Howell and Altounyan's (1967) failure to show objective improvement in patients whose symptoms were diminished by disodium cromoglycate was due to the unreliability of isolated measurements in asthmatic patients. The value of daily measurements of P.E.F. recommended by Epstein et al. (1969) is confirmed by this study.

Grant (1968) criticized claims that have been made of benefit from disodium cromoglycate on the ground that the degree of improvement obtained has been too small to be worth while in most cases. It can be seen from our results that there was a very marked symptomatic improvement in the nine patients who were benefited and that they showed on average a $30 \%$ improvement in P.E.F. rate accompanied by a $65 \%$ improvement in specific conductance. These changes appear to us to be well worth while.

We wish to thank Dr. C. M. Fletcher, Dr. E. J. M. Campbell, Dr. J. B. L. Howell, and Dr. N. L. Jones for advice and criticism; Dr. R. E. C. Altounyan, of Fisons Pharmaceuticals Ltd., for his advice and for arranging supplies of the drug; and Miss Jan Newton-Howes for her technical assistance.

One of us (D. G. R.) is supported by a grant from the Tobacco Research Council, and one (S. W. E.) was in receipt of the Henry A. Beatty Scholarship and of a bursary from the Canadian Friends of the Royal Postgraduate Medical School.

\section{REFERENCES}

Altounyan, R. E. C. (1964). Thorax, 19, 406

Alytounyan, R. E. C., and Howell, J. B. L. (1967). Proceedings of Davos Symposium. To be published in Respiration.

Campbell, E. J. M., and Howell, J. B. L. (1962). Brit. med. F., 2, 630.

Epstein, S. W., Fletcher, C. M., and Oppenheimer, E. A. (1969). Brit. med. F., 1, 223.

Grant, I. W. B. (1968). Lancet, 2, 282.

Guyatt, A. R., Alpers, J. H., and Davies, E. E. (1967a). F. appl. Physiol., $22,390$.

Guyatt, A. R.. Alpers, J. H., Hill, I. D., and Bramley, A. C. (1967b). f. appl. Physiol., 22, 383 .

Howell, J. B. L., and Altounyan, R. E. C. (1967). Lancet, 2, 539.

Jones, N. L., Campbell, E. J. M., McH ardy, G. J. R., Higgs, B. E., and Clode, M. (1967). Clin. Sci., 32, 311.

McDermott, M., McDermott, T. J., and Collins, M. M. (1968). Med. biol. Engng, 6, 291.

Medical Research Council (1965). Lancet, 1, 775.

Moran, F., Bankier, J. D. H., and Boyd, G. (1968). Lancet, 2, 137.

Pepys, J., Hargreave, F. E., Chan Moira, and McCarthy, D. S. (1968). Lancet, $2,134$.

Woolcock, A. J., and Read, J. (1966). Amer. F. Med., 41, 259.

\section{Preliminary Communications}

\section{Progesterone Oral Contraception and Blood Coagulation}

Brit. med. F., 1969, 1, 554-556

$S^{\min }$ ummary : The effects on blood coagulation of oral contraception with continuous progesterone (chlormadinone acetate, $0.5 \mathrm{mg}$. daily) have been studied in a group of 76 volunteers. The women in this trial not having previously received conventional oral contraceptives showed no evidence of increased coagulability or increased platelet aggregation in the first three months, though possibly fibrinolytic activity was raised. Women previously taking combined oestrogen-progesterone preparations showed significantly raised levels of clotting. factors VII and X at the start of the trial. Both of these progressively fell over the three months, and by the third month the factor VII level was no longer different from the normal group. Factor $X$ levels, however, have not yet fallen to normal. The results so far suggest that the thrombogenic constituent of conventional oral contraception may have been eliminated by the use of progesterone alone, though further investigation will be required to substantiate this.

\section{INTRODUCTION}

Oral contraception with conventional oestrogen-progesterone combinations produces significant rises in specific bloodclotting factors-that is, factors VII and X (Thomson and Poller, 1965). The rise becomes significant from the third 